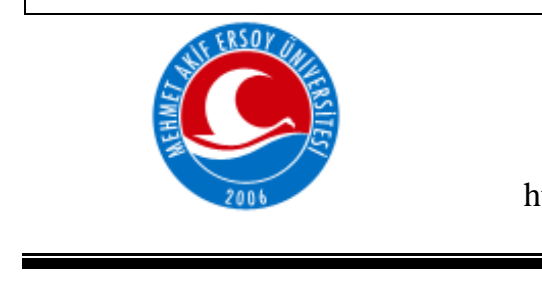

\author{
MEHMET AKIF ERSOY ÜNIVERSITESI \\ SAĞLIK BİLIMLERİ ENSTITÜSÜ DERGİSi \\ "MAKÜ Sag. Bil. Enst. Derg." \\ http://edergi.mehmetakif.edu.tr/index.php/sabed/index
}

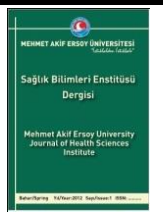

\title{
Toll Benzeri Reseptörler
}

\author{
Toll-like Receptors
}

\author{
Mehmet Özbek $^{1}$, Mustafa Hitit ${ }^{2}$, Emel Ergün ${ }^{3}$, Feyzullah Beyaz $^{4}$, Levent Ergün ${ }^{3}$ \\ Mehmet Akif Ersoy Üniversitesi, Veteriner Fakültesi, Histoloji Embriyoloji Anabilim Dalı, BURDUR, TÜRKIYE \\ Selçuk Üniversitesi, Veteriner Fakültesi, Genetik Anabilim Dalı, KONYA, TÜRKIYYE \\ Ankara Üniversitesi, Veteriner Fakültesi, Histoloji Embriyoloji Anabilim Dalı, ANKARA, TÜRKIYE \\ Erciyes Üniversitesi, Veteriner Fakültesi, Histoloji Embriyoloji Anabilim Dalı, KAYSERİ, TÜRKIYE
}

\begin{abstract}
Innate immunity constitutes the organism's first line of defense by initiating inflammatory response as well as phagocytosis to microbial attacks. This inflammatory response occurs as a consequence of induction of Pattern recognition receptors (PRR), which are germline-encoded in the organism. While PRRs primarily recognize microbial pathogen-associated molecular patterns (PAMP), they also react with substances secreted by the organism itself in situations such as stress, tissue damage, and necrotic cell death. PRRs are divided into several subtypes, among which the most well-defined Toll-like receptors (TLRs). Different toll-like receptors have been described in humans 10 (TLR1TLR10) and in mice 12 (TLR1-TLR9, TLR11-TLR13).TLRs localize to the cell surface or intracellular compartments such as endosomes, lysosomes, and endolysosomes. TLRs can be expressed in immune system cells, such as macrophages and dendritic cells, as well as cells that are not involved in the immune system, such as fibroblast and epithelial cells. TLRs are not found in the cell or on the surface alone and form homodimers themselves or heterodimers with their coreceptors and accessory molecules. TLRs on the cell surface mainly recognize microbial membrane components such as lipids, lipoproteins, and proteins While intracellular TLRs recognize nucleic acids derived from bacteria and viruses. In addition, intracellular TLRs may recognize self-nucleic acids and cause autoimmune diseases.

Studies conducted in recent years have shown that TLRs are associated with the pathogenesis of cancer and autoimmune diseases and it is thought that agonists or antagonists used against these receptors in later years may be useful in the treatment of these diseases.
\end{abstract}

Key words: Innate immunity, pattern recognition receptors, tolllike receptors

Yazışma Adresi: Arş. Gör. Mehmet Özbek, Mehmet Akif Ersoy Üniversitesi, Veteriner Fakültesi, Histoloji Embriyoloji Anabilim Dalı, BURDUR, TÜRKIYYE E-posta: mozbek@mehmetakif.edu.tr

Telefon: 00902482132049
Öz: Doğal bağışıklık polimorfnükleer lökosit, monosit, makrofaj, eozinofil granülosit, mast hücresi ve bazofil granülosit gibi özelleşmiş hücrelerden ve moleküllerden meydana gelir. Mikrobiyal saldırılara karşı bu hücrelerin bazıları fagositoz yaparak inflamatuvar yanıtı başlatırlar ve organizmanın ilk koruma hattını oluştururlar. Organizmada, bu inflamatuvar yanıta, kalıtımsal olarak aktarılan, patern tanıyan reseptörlerin (PRR) uyarılması da katkı sağlar. PRR'ler hem mikrobiyal patojenle ilişkili moleküler kalıpları (PAMP) tanırlar, hem de doku hasarı ve nekrotik hücre ölümü gibi stres faktörleri altında kalan organizmanın kendisi tarafindan salgılanan maddelere immun reaksiyon gösterirler. PRR'ler birçok alt tipe ayrılır. Bunlar içerisinde en iyi tanımlananlar Toll Benzeri Reseptörlerdir (Toll Like Receptors, TLR). İnsanlarda 10 (TLR1-TLR10), farelerde ise 12 (TLR1-TLR9, TLR11-TLR13) farklı TLR tanımlanmıştır. TLR'ler hücre yüzeyine veya endozom, lizozom, endolizozom gibi hücre içi kompartımanlara lokalize olurlar. Bu moleküller makrofaj ve dendritik hücreler gibi immun sistem hücrelerinin yanında fibroblast ve epitel hücreleri gibi immun sistem dışındaki hücrelerde de eksprese edilebilir. TLR'ler kendileriyle homodimer veya koreseptörleri ve aksesuar molekülleriyle heterodimer oluştururlar. Hücre yüzeyinde bulunan TLR'ler öncellikle lipid, lipoprotein, protein gibi mikrobiyal membran bileşenlerini tanırlar. Buna karşın hücre içindeki TLR'ler bakteri ve virüs orjinli nükleik asitleri algılarlar. Ayrıca vücudun kendi nükleik asitlerini tanıyıp otoimmun hastalıklara neden olabilirler.

Son yıllarda yapılan çalışmalarda, kanser ve otoimmun hastalıkların patogenezinde TLR'lerin rolü olduğu gösterilmiştir. İlerleyen yıllarda bu reseptörlere karşı kullanilan agonist veya antogonistlerin belirtilen hastalıkların sağaltımında faydalı olabileceği ileri sürümektedir.

Anahtar sözcükler: Doğal bağışıklık, patern tanıyan reseptörler, toll benzeri reseptörler

Geliş Tarihi: 21.08.2017～Kabul Tarihi: 27.11.2017 


\section{Giriş}

Memeliler, doğal ve kazanılmış olmak üzere iki tip bağışıklık sistemine sahiptirler. Doğal bağışıklık sisteminin 1990'ların ortalarına kadar kompleks olmayan yapılara sahip olduğu düşünülürken, ilerleyen zaman içinde bunun doğru olmadığı, tıpkı kazanılmış bağışıklık gibi ileri derecede karmaşık bir mekanizmaya sahip olduğu belirlendi (Kumar ve ark., 2011). Doğal bağışıklık sistemi mikrobiyal saldırılara karşı fagositoz yanında inflamatuvar yanıtı başlatarak organizmanın ilk koruma hattını oluşturur. Bu inflamatuvar yanıt organizmada kalıtımsal olarak aktarılan, patern tanıyan reseptörlerin (PRR) uyarılması sonucu meydana gelmektedir. PRR'ler hem mikrobiyal patojenle ilişkili moleküler kalıpları (PAMP) tanır hem de stres, doku hasarı ve nekrotik hücre ölümü gibi durumlarda organizmanın kendisi tarafından salgılanan maddelere de immun reaksiyon gösterirler (Broz ve Monack, 2013). Bunlara ek olarak PRR'ler apoptozisin düzenlemesi, DNA tamiri, otofaji, anjiyogenez gibi önemli süreçlerde de görev almaktadırlar (Kutikhin ve Yuzhalin, 2015). PRR'ler protein bölgelerinin homolojisine göre beş farklı reseptör ailesinden oluşur. Bunlar; Toll benzeri reseptörler (TLR), NOD benzeri reseptörler (NLR), C tip lektin reseptörler (CLR), RIG-I benzeri reseptörler (RLR) ve AIM2 benzeri reseptörlerdir (ALR). Bunlar içinde en iyi tanımlanan TLR'lerdir (Kumar ve ark., 2011). TLR'ler evrimsel süreçte solucan türü olan Caenorhabditis elegans'tan memelilere kadar korunmuştur (Janeway ve Medzhitov, 2002; Hoffmann, 2003; Akira ve Takeda, 2004; Beutler, 2004). Toll başlangıçta Drosophila'nın embriyonal dorsoventral polaritesinin gelişiminde esansiyel bir gen olarak tanımlanmıştır. İlerleyen yıllarda yapılan çalışmalarda bu genin susturulması sonucu sineklerin mantar enfeksiyonlarından öldüğünün tespit edilmesiyle, bu genin aynı zamanda antifungal etkisinin de olduğu belirlenmiştir (Lemaitre ve ark., 1996).

\section{TLR Yapısı}

Bütün TLR'ler, hastalık etkenlerine eşlik eden moleküler yapılar (PAMP) ve hasarla ilişkili moleküler yapıları (Damage associated moleculer pattern, DAMP) tanıyan at nalı biçimindeki proteinlerdir. Moleküler ağırlıkları 90 ila $115 \mathrm{kDa}$ arasında değişen ve 16-28 hücre dış1 lösin zengin tekrarlardan (LRR) oluşan bir ektodomain ile IL-1 reseptörüne benzer olduğu için TIR (toll like/Interleukin 1) ismini alan sinyal iletiminde görevli bir transmembran kısmına sahiptirler. TLR'lerin transmembran a-heliks kısmı ve korunmuş iç bölgesi insanlardaki interlökin reseptör1 (IL-1R) ve interlökin reseptör 18 (IL-18R) in 
homoloğudur (Beutler ve ark., 2006). TLR'ler kendileriyle homodimer şeklinde veya koreseptörleri ve aksesuar molekülleriyle heterodimer şeklinde görülürler (Botos ve ark., 2011).

\section{PAMP'ların TLR ile Tanınması}

İnsanlarda 10 (TLR1-TLR10), farelerde ise 12 (TLR1-TLR9, TLR11-TLR13) farkl1 TLR tanımlanmıştır. TLR'ler hücre yüzeyine veya endozom, lizozom, endolizozom gibi hücre içi kompartımanlara lokalize olurlar. TLR1, TLR2, TLR4, TLR5, TLR6 ve TLR10 hücre yüzeyinde lokalize olurken TLR3, TLR7, TLR8, TLR9, TLR11, TLR12 ve TLR13 hücre içinde endozomlarda bulunurlar. TLR'ler makrofaj ve dendritik hücreler gibi immun sistem hücrelerinin yanında fibroblast ve epitel hücreleri gibi immun sistem dişındaki hücrelerde de eksprese edilebilirler (Kawai ve Akira, 2010; Celhar ve ark, 2012).

Hücre yüzeyinde bulunan TLR'ler öncellikle lipid, lipoprotein, protein gibi mikrobiyal membran bileşenlerini tanırlar. TLR4 bakteriyel lipopolisakkaritleri, TLR5 bakteriyal flagellin, TLR1 veya TLR6 ile heterodimer oluşturan TLR2 tGPI-musin, lipoprotein, peptidoglikan, mannan, zimozan, lipoteikoik asit gibi PAMP'ları tanıma özelliğine sahiptirler (Kawai ve Akira, 2010). TLR10 farelerde stop kodon eksikliği sonucu oluşan pseudo genleri tanırken insanlarda TLR2 ile heterodimer oluşturup Listeria kökenli ligandları tanır. TLR10 aynı zamanda influenza A enfeksiyonlarına karşı duyarlıdır (Lee ve ark, 2014).

İntraselüler TLR'ler bakteri ve virüs orjinli nükleik asitleri algılarlar (Blasius ve Beutler, 2010). TLR3 viral çift sarmallı RNA'yı, küçük interferans RNA'yı ve zarar görmüş hücrelerden ortaya çıkan self RNA'ları tanımaktadır. TLR7 genelde plasmasitoid dendritik hücrelerde bulunur ve tek sarmallı viral RNA'yı tanır. Aynı zamanda klasik dendritik hücrelerde de bulunup Streptococcus B'nin RNA sını algılar. İnsanlarda TLR8 bakteriyal ve viral RNA ya karşı immun yanıtı başlatmaktadır. TLR13 bakteriyel 23s rRNA (Oldenburg ve ark., 2012) ve vezikular stomatitis etkeninin bilinmeyen bir kompanentini tanır (Shi ve ark., 2011). TLR9 metillenmemiş CpG motiflerinden zengin viral ve bakteriyel DNA'yı, aynı zamanda Plasmodium falciparum enfeksiyonlarında ortaya çıkan çözünmez kristal özelliğe sahip homozoin maddesini algilar (Coban ve ark., 2010). Endozomlarda lokalize olan ve geniş bir tanıma spektrumuna sahip olan TLR11 flagellin (Mathur ve ark., 2012), üropatojenik Escherichia coli nin bilinmeyen proteinaceous kompanenti ve Toxoplasma gondii kökenli profilin benzeri molekülleri tanıyıp bunlara karşı immun yanıtın başlamasına 
aracıl1k eder (Yarovinsky ve ark., 2005). Çoğunlukla myeloid hücrelerde ekprese olan TLR12, PAMP'ları tanıma açışından TLR11 büyük benzerlik gösterip Toxoplasma gondii kökenli profilin benzeri molekülleri tanır (Koblansky ve ark., 2013). TLR12 homodimer şeklinde veya TLR11 ile heterodimer oluşturarak yerleşim gösterir (Andrade ve ark., 2013; Broz ve Monack, 2013).

\section{TLR'lerin Sentezi ve Hücredeki Döngüsü}

Bütün TLR'ler endoplazmik retikulumda sentezlenip Golgi kompleksinde olgunlaştırılır. $\mathrm{Bu}$ aşamadan sonra hücre yüzeyine veya endozom gibi intraselüler kompartımanlara taşınırlar. İntraselüler TLR'ler ligandları tanıma açısından kritik öneme sahiptir. Bazı patolojik durumlarda self nükleik asitleri tanıyı otoimmun hastalıklara yol açabilirler (Sasai ve ark., 2010; Lee ve ark., 2013). Multi transmembran bir protein olan UNC93B1, intraselüler TLR'leri endoplazmik retikulumdan endozomlara geçişini kontrol eden yapılardan birisidir. İlginç bir şekilde aşırı TLR7 aktivasyonunda UNC93B1, TLR9'un endozomlara taşınmasını artırarak aşırı TLR7 aktivasyonunun zararlı etkilerini önlemektedir (Fukui ve ark., 2009). TLR lerin görev yerlerine akışını sağlayan diğer bir protein ise endoplazmik retikulumda yer alan PRAT4A'tür. PRAT4A TLR1, TLR2, TLR4, TLR7 ve TLR9'un endoplazmik retikulumdan hücre yüzeyine yada endozomlara taşınmasını kontrol eder (Takahashi ve ark., 2007). Endoplazmik retikulum kökenli 1sı şok protein 90 (heat shock protein 90) ailesinin bir üyesi olan gp96, hücre yüzeyinde yer alan TLR1, TLR2, TLR4, TLR5 ile hücre içinde yer alan TLR7 ve TLR9 için şaperon proteini olarak görev yapar (Yang ve ark., 2007). Endozomlarda nükleik asitleri tanıyan TLR'lerin ligandları tanıyıp sinyal iletimini gerçekleştirebilmesi bir takım proteolitik enzimlerin (Katepsin B, S, L, H, K ve asparjinil endopeptidaz) etkisi ile bölünüp aktif forma dönüşmeleri gerekir (Ewald ve ark., 2011; Garcia-Cattaneo ve ark., 2012).

\section{TIR-Bölgesi Adaptör Proteinleri}

TLR'ler ve IL-1R ailesi üyeleri tarafından başlatılan sinyalin iletilmesi için MyD88, TIRAP / MAL, TRIF, TRAM ve SARM gibi adaptör proteinlere ihtiyaç vardır. Bu adaptör proteinler NF-кB, IRF1, IRF3, IRF5, IRF7 ve interferon- $\gamma$ gibi transkripsiyon faktörlerini aktive etmek için etkileşime girerler (Narayanan ve Park, 2015). 


\section{MyD88}

Miyeloid diferansiyasyon faktör 88 (MyD88), kısa bir bağlayıcı dizisi ve karboksil (C)- terminal TIR bölgesini takip eden amino (N)-terminal death domaine (DD) sahiptir. Ayrıca IL-1R ilişkili kinaz 4 (IRAK4) ile etkileşime giren dolayısıyla TLR sinyalizasyonu için gerekli olan bir intermediyet domain (ID) de bulunur (Burns ve ark., 2003). MyD88 knockout farelerin TLR4'ün ligandı olan LPS'ye, TLR2 ligandlar1 olan peptidoglikanlara ve lipoproteinlere, TLR9'un ligandı metillenmemiş CpG DNA motiflerine, TLR7 ligandı imidazoquinoline ve TLR5 ligandı flagelline karşı immun reaksiyon vermediği görülmüştür. $\mathrm{Bu}$ bulgular göz önüne alındığında, söz konusu adaptör molekülün TLR ailesi üyelerinin aracılık ettiği inflamatuvar yanıttaki rolünü ortaya koymuştur (Narayanan ve Park, 2015).

\section{TIRAP/MAL}

TIR bölgesi içeren adaptör molekül (TIRAP) veya MyD88 adaptör benzeri (MAL) protein ismi verilen bu molekül TLR1/2, TLR2/6, TLR4 heterodimer ve homodimerleri yanında diğer bir adaptör molekül olan MyD88’ten gelen sinyalin iletilmesinde görev yapar (Yamamoto ve ark., 2002; Horng ve ark., 2002).

\section{TRIF}

Bir başka adaptör molekül ise TIR bölgesi içerip interferon- $\beta$ salınımı indükleyen TRIF'tir. Bu molekül aynı zamanda TIR bölgesi içeren molekül 1 (TICAM1) diye de isimlendirilir. TRIF, insanlarda 712 amino asit içeren büyük bir proteindir. TRIF'nin MyD88 ve MAL ile birlikte aşırı ekspresyonu, insan embriyonik böbrek 293 (HEK-293) hücrelerinde NF-kB (nuclear factor kappa-light-chain-enhancer of activated B cells)'ye bağımlı promotörleri aktive ederken, TRIF'in yalnız başına aşırı ekspresyonu interferon- $\beta$ (IFN- $\beta$ ) salınımını sağlayan moleküllerin aktivasyonunu başlatmıştır. TRIF knockout farelerde hem TLR3 ve TLR4 aracılı IFN- $\beta$ üretiminde hem de IFN-indüklenebilir genlerin ekspresyonunda bozukluklar görülmüştür (Yamamoto ve ark., 2003; Narayanan ve Park, 2015).

\section{TRAM}

Bu molekül TRIF ile ilişkili adaptör molekül (TRAM) veya TIR alanı içeren molekül 2 (TICAM2) olarak bilinir. TRAM, veritabanı aramalarında dizi homolojisiyle tanımlanan dördüncü TIR bölgesi içeren adaptör moleküldür (Bin ve ark., 2003;Yamamoto ve ark., 2003). TRAM knockout farelerde, TLR4 uyarımına cevap olarak görev yapan ineterferon 
regülatör faktör 3 (IRF3)'ün ve IFN-indüklenebilir genlerin ekspresyonunu azaldığ1 görülmüştür. TRAM knockout farelerin TRIF eksikliği olan farelerin aksine TLR3 uyarısına normal cevap verdiği gözlenmiştir (Fitzgerald ve ark., 2003; Oshiumi ve ark., 2003). Bu bulgular göz önüne alındığında TRAM'ın TRIF ve TLR4 ile sinyalizasyonda görev aldığı belirlenirken, TLR3'ün sinyal iletilmesinde görevi olmadığı anlaşılmıştır. TRAM özellikle TLR4 aktivasyonu sonucu MyD88'den bağımsız / TRIF'e bağımlı sinyal yolağında sinyal iletilmesi için gerekli adaptör moleküldür (Narayanan ve Park, 2015).

\section{SARM}

Steril $\alpha$ ve HEAT/Armadillo motifi içeren protein (SARM), 2001'de insan genomunun araştırılması sonucu tanımlanmış TIR bölgesi içeren adaptör proteindir. SARM 690 amino asit içerir. Bu aminoasitlerin dizilimi Drosophila melanogaster ve Caenorhabditis elegans'in proteinlerine yüksek derecede benzerlik göstermektedir. İn vitro çalışmalar, insan SARM'ının TLR3 ve TLR4'ün MyD88'den bağımsız sinyal vermesine aracılık eden TRIF adaptör proteininin fonksiyonunu engellediğini göstermiştir (Carty ve ark., 2006; Szretter ve ark., 2009).

\section{Üreme Sisteminde TLR Ekspresyonu}

TLR'lerin testislerde hem dendritik hücre ve makrofajlar gibi immun sistem hücrelerinde hem de bu sistem dişındaki hücrelerde ekspresyonu görülmektedir (Shang ve ark., 2011). Siçan ve fare Sertoli hücrelerinde TLR2, TLR3, TLR4 ve TLR5 ekspresyonu gözlenmiştir. Sıçanlarda bunlara ek olarak TLR4 ün yardımc1 reseptörleri olan CD14 ve MD2 Sertoli hücrelerinde görülmesi TLR4'ün testisteki ekpresyonunu doğrulamıştır. Ayrıca sıçan Sertoli hücrelerinde (Bhushan ve ark., 2008) TLR1, TLR10 ve TLR11 mRNA ekspresyonu gözlenirken, fare Sertoli hücrelerinde düşük seviyelerde TLR6, TLR7 ve TLR13 mRNA tespit edilmiştir (Riccioli ve ark., 2006). Siçanlarda bazı aşamadaki spermatogenik hücrelerde TLR2, TLR3 ve TLR 4, peritubuler myoid hücrelerde TLR2, TLR3, TLR4, TLR6 ve TLR11, Leydig hücrelerinde ise TLR2, TLR3, TLR4, MD2, CD14 ve TLR10 mRNA ekspresyonu görülmüştür (Bhushan ve ark., 2008;Shang ve ark., 2011;Winnall ve ark., 2011). Siçanlarda epididimiste yapılan çalımalar TLR11 hariç diğer bütün TLR'lerin epididimisi oluşturan epitelde lokalize olduklarını göstermiştir (Palladino ve ark., 2008).

Dişi genital kanalının mukozası da işgalci mikroorganizmalara karşı ilk savunma hattını sağlar. Epitelde TLR'lerin varlığı doğal ve adaptif bağışık yanıtların başlatılması ve 
iletişiminin ayrılmaz bir parçasıdır (Medzhitov ve Janeway, 2002). Yapılan çalışmalar vajina ve serviksteki epitel hücrelerinde TLR1, TLR2, TLR3, TLR5 ve TLR6 ekprese olduğunu göstermiştir (Fichorova ve ark., 2002). Andersen ve ark. (2006), insan servikal epitel hücre kültürlerinin TLR3, TLR9 ve TLR7 için mRNA eksprese ettikleri fakat TLR8 için zayıf ekspresyon olduğunu bildirmişlerdir. TLR4 ekspresyonu çoğunlukla dişi üreme sisteminin üst bölümlerinde gözlenirken, vajina ve ektoservikste bu ekspresyon görülmemiştir (Fichorova ve ark., 2002; Andersen ve ark., 2006). Aflatoonian ve ark. (2007), insan endometriumdan aldıkları biyopsilerde TLR1-10 mRNA ekspresyonu tespit etmişlerdir. Bir çok çalışmada ovaryumlarda TLR1, TLR4, TLR5 ve TLR6 için mRNA ekspresyonu olduğu bildirilmiştir (Rock ve ark., 1998; Takeuchi ve ark., 1999; Zarember ve ark., 2002; ). Gelişmekte olan foliküllerinin granulosa hücrelerinde ve ovulasyon sirasında serbest bırakılan kumulus oosit kompleksinde TLR4, TLR8 ve TLR9'un protein ekspresyonu gösterilmiştir (Rock ve ark., 1998; Takeuchi ve ark., 1999; Zarember ve ark., 2002; Girling ve ark., 2007; Herathve ark., 2007). İnsanlarda tuba uterinada ise TLR7, TLR8, TLR9 ve TLR10 mRNA düzeyinde tespit edilmiştir (Ghasemi ve ark., 2014).

\section{Gastrointestinal Kanalda TLR Ekspresyonu}

TLR'leri eksprese edebilen makrofajlar, dendritik hücreler, B hücreleri, T hücreleri ve stromal hücreler gibi birçok hücre tipi bağırsakta yer aldığından tüm bağırsak dokuları kullanılarak TLR'lerin spesifik olarak intestinal epitel hücrelerindeki mRNA ekspresyonunun belirlenmesi zordur. İmmunohistokimya, enzimatik hücre ayırma vb diğer yöntemler kullanılarak sağlıklı insan kolonundaki epitel hücrelerin TLR2 ve TLR4'ün düşük seviyelerde eksprese edildiği bildirilmiştir (Cario ve Podolsky, 2000; Abreu ve ark., 2001; Otte ve ark., 2004; Abreu, 2010). TLR3 sağl1klı insan ince bağırsak ve kolonunun her ikisinde bol miktarda eksprese edilirken, TLR5 yoğun olarak kolonda eksprese edilir (Cario ve Podolsky, 2000). Bununla birlikte TLR1, TLR2, TLR3, TLR4, TLR5 ve TLR9 ince bağırsak epitel hücrelerinde eksprese edilmektedir. İnsan kolonunda hemen hemen bütün TLR'ler, en azından mRNA düzeyinde ekspresyon gösterir (Otte ve ark., 2004; Abreu, 2010). Gastrik epitelde ise TLR2, TLR4 ve TLR5 ekpresyonu tespit edilmiştir (Cario ve Podolsky, 2000; Smith ve ark., 2003). 


\section{Solunnum Sisteminde TLR Ekspresyonu}

Solunum yolu epitel hücreleri tozlara, mikroorganizmalara, gazlara ve diğer alerjenlere karşı vücudun ilk savunma hattını oluştururlar. Yapılan çalışmalar insan solunum yolu epitelinde TLR1, TLR2, TLR3, TLR4, TLR5, TLR6 ve TLR9'un eksprese olduğunu göstermiştir (Sha ve ark., 2004). İn vitro çalışmalar TLR8 dışında tüm TLR'lerin insan solunum yolu epitel hücre hattı olan BEAS-2B'de bulunduğu, primer bronşiyal epitel hücre hatlarında ise TLR1'den TLR10'a kadar olan bütün TLR'lerin eksprese edildiğini göstermiştir. Fakat bu primer hücre kültür hattındaki hücrelerde TLR2, TLR3, TLR4 ve TLR5'in yüksek düzeyde TLR7, TLR8 ve TLR10'un ise düşük düzeyde ekprese edildiği gözlenmiştir (Chen ve ark., 2011). Bununla birlikte aveolar makrofajlarda zayıf TLR3, TLR5 ve TLR9 ekpresyonu, yüksek düzeyde TLR1, TLR2, TLR4, TLR7, TLR8 ekspresyonu olduğu bildirilmiştir (Lafferty ve ark., 2010).

\section{Sinir Sisteminde TLR Ekspresyonu}

Merkezi sinir sistemindeki nöronlarda öncelikle TLR3, TLR7, TLR8, TLR9 gibi intraselüler TLR'lerin ekpresyonu görülmektedir. Nöronlarda aynı zamanda CD14 ve MD1 ile etkileşime giren TLR4 ekspresyonu da bildirilmiştir (Tang ve ark., 2007; Hanke ve Kielian, 2011). Periferal sinir sistemindeki çalışmalarda ise Schwann hücrelerinde TLR3, TLR4 ve TLR7'nin oldukça iyi ekpresyon gösterdiği tespit edilmiştir. Motor nöronlarda dominant olarak TLR2, TLR3 ve TLR5 ekspresyonu gözlenirken duyusal nöranlarda ise TLR3, TLR4, TLR5 ekspresyonu gözlenmektedir. Ne motor nöronlarda ne de duyusal nöronlarda net bir şekilde TLR7, TLR8, TLR9 ekspresyonu belirlenememiştir (Goethals ve ark., 2010). Mikrogliyalarda TLR1'den TLR9'a kadarki bütün TLR'ler gözlenirken TLR10 ekspresyonu tespit edilememiştir. İnsan primer astrositler kültürlerinde mRNA düzeyinde TLR1-7, TLR9 ve TLR10 tespit edilirken (Jack ve ark., 2005), fare astrositlerinde yine mRNA düzeyinde TLR1-6 olduğu belirlenmiştir (Bowman ve ark., 2003). Diğer gliyal hücrelerle karşılaştırıldığında oligodendrositlerdeki TLR ekspresyonu hakkında çok az bilgi mevcuttur. Çalışmalar oligodendrositlerde TLR2 ve TLR3'ün diğer TLR'lere göre nispeten fazla miktarda eksprese olduğunu göstermektedir (Bsibsi ve ark., 2002; Lehnardt ve ark., 2006). Ayrıca Lin ve ark. (2013) retinadaki Müller hücrelerinde mRNA düzeyinde TLR2, TLR3, TLR4 ve TLR5'i tespit etmişlerdir. 


\section{Tümör Hücrelerinde TLR Ekspresyonu}

TLR'ler tümör hücrelerinde de ekpresyon gösterebilir (Shatz ve ark., 2012; Ridnour ve ark., 2013; Ming ve ark., 2014). Kanserin progresyonunda hem immun sistem hücrelerindeki hem de tümörlerdeki TLR'lerin ilişkili olduğu bilinmektedir (DeCarlo ve ark., 2011; Ridnour ve ark., 2013). TLR'ler tümör kaynaklı antijenleri tespit eden ve primer anti-tümör bağışıklık yanıtını uyandıran immun sistemin temel sensör molekülleri olarak görev yapmaktadır (Ito ve ark., 2002). Aktive edilmiş TLR'ler efektör hücrelerde sitotoksik aktiviteyi tetikleyerek sinyalizasyon yolakları uyarır ve tümör hücrelerinin lizisine neden olur (Kalb ve ark., 2012). Tümör hücrelerin TLR'ler aracılığıyla zamanında ortadan kaldırılması, inflamatuvar tümör mikro çevrenin oluşmasına da önleyebilir (Pisetsky ve ark., 2011). Bununla birlikte farklı TLR'lerin kanser gelişiminde zıt etkilere sahip olduğu bildirilmiştir (Cai ve ak., 2011; Ming ve ark., 2014). Tümör hücreleri bazı durumlarda immun supresif etkili bazı TLR'leri aktive ederek sitotoksik hücre sayısının azalmasına, proinflamatuvar faktörlerin artmasına neden olur. Bu sürece anormal reperasyon eşlik edip en son tümöral invazyon ile sonuçlanır (Chen ve ark., 2008).

\section{Sonuç}

Sonuç olarak, TLR'ler organizmada hemen hemen bütün sistemlerde immun sistem hücreleri ile birlikte bazı diğer hücrelerde ekspresyon göstermektedir. Son y1llarda yapılan çalışmalarda kanser ve otoimmun hastalıkların patogenezisi ile TLR'lerin ilişkisi ortaya çıkarılmıştır. İlerleyen yıllarda bu reseptörlere karşı kullanılan agonist veya antogonistlerin söz konusu hastalıkların sağaltımında faydalı olabileceği ileri sürülmüştür.

\section{Kaynaklar}

1. Abreu MT, Vora P, Faure E, Thomas LS, Arnold ET, Arditi M. 2001. Decreased expression of Toll-like receptor-4 and MD-2 correlates with intestinal epithelial cell protection against dysregulated proinflammatory gene expression in response to bacterial lipopolysaccharide. $\mathbf{J}$ Immunol. 167(3): 1609-1616.

2. Abreu MT. 2010. Toll-like receptor signalling in the intestinal epithelium: how bacterial recognition shapes intestinal function. Nat Rev
Immunol.

10(2):

131-144.

3. Aflatoonian R, Tuckerman E, Elliott SL, Bruce C, Aflatoonian A, Li TC, Fazeli A. 2007. Menstrual cycle-dependent changes of Toll-like receptors in endometrium. Hum Reprod. 22(2): 586-593.

4. Akira S, Takeda K. 2004. Toll-like receptor signalling. Nat Rev Immunol. 4: 499-511. 
5. Andersen JM, Al-Khairy D, Ingalls RR. 2006. Innate Immunity at the Mucosal Surface: Role of Toll-Like Receptor 3 and Toll-Like Receptor 9 in Cervical Epithelial Cell Responses to Microbial Pathogens. Biol. Reprod. 74(5): 824831.

6. Andrade WA, Souza Mdo C, Ramos-Martinez E, Nagpal K, Dutra MS, Melo MB, Bartholomeu DC, Ghosh S, Golenbock DT, Gazzinelli RT. 2013. Combined action of nucleic acid-sensing Toll-like receptors and TLR11/TLR12 heterodimers imparts resistance to Toxoplasma gondii in mice. Cell Host Microbe.13(1): 42-53.

7. Beutler B. 2004. Inferences, questions and possibilities in Toll-like receptor signalling. Nature. $\quad 430$ : 257-263.

8. Beutler B, Jiang Z, Georgel P, Crozat K, Croker B, Rutschmann S, Du X, Hoebe K. 2006. Genetic analysis of host resistance: Toll-like receptor signaling and immunity at large. Annu. Rev. Immunol. 24: 353-389.

9. Bhushan $S$, Tchatalbachev S, Klug J, Fijak M, Pineau C, Chakraborty T, Meinhardt A. 2008. Uropathogenic Escherichia coli block MyD88dependent and activate MyD88-independent signaling pathways in rat testicular cells. J Immunol. 180(8): 5537-5547.

10. Bin LH, Xu LG, Shu HB. (2003). TIRP, a novel Toll/interleukin-1 receptor (TIR) domaincontaining adapter protein involved in TIR signaling. J Biol Chem. 278(27): 24526-24532.

11. Blasius AL, Beutler B. 2010. Intracellular tolllike receptors. Immunity. 32(3): 305-315.

12. Botos I, Segal DM, Davies DR. 2011. The structural biology of Toll-like receptors. $\begin{array}{lll}\text { Structure. } & \text { 19(4): }\end{array}$

13. Bowman CC, Rasley A, Tranguch SL, Marriott I. Cultured astrocytes express toll-like receptors for bacterial products. Glia. 43(3): 281-291.

14. Broz P, Monack DM. 2013. Newly described pattern recognition receptors team up against intracellular pathogens. Nat Rev Immunol. 13(8): $551-565$

15. Bsibsi M, Ravid R, Gveric D, van Noort JM. 2002. Broad expression of Toll-like receptors in the human central nervous system. J Neuropathol Exp Neurol. 61(11): 1013-1021.

16. Burns K, Janssens S, Brissoni B, Olivos N, Beyaert R, Tschopp J. 2003. Inhibition of interleukin 1 receptor/Toll-like receptor signaling through the alternatively spliced, short form of MyD88 is due to its failure to recruit IRAK-4. J Exp Med. 197(2): 263-268.

17. Cai Z, Sanchez A, Shi Z, Zhang T, Liu M, Zhang D. 2011. Activation of Toll-like receptor 5 on breast cancer cells by flagellin suppresses cell proliferation and tumor growth. Cancer Res. 71(7):

2466-2475.

18. Cario E, Podolsky DK. 2000. Differential alteration in intestinal epithelial cell expression of toll-like receptor 3 (TLR3) and TLR4 in inflammatory bowel disease. Infect Immun. 68(12):

7010-7017.

19. Carty M, Goodbody R, Schröder M, Stack J, Moynagh PN, Bowie AG. 2006. The human adaptor SARM negatively regulates adaptor protein TRIF-dependent Toll-like receptor signaling. Nat Immunol. 7(10): 1074-1081.

20. Celhar T, Magalhaes R, Fairhurst AM. 2012. TLR7 and TLR9 in SLE: when sensing self goes wrong. Immunol Res. 53: 58-77.

21. Chen R, Alvero AB, Silasi DA, Steffensen KD, Mor G. 2008. Cancers take their Toll--the function and regulation of Toll-like receptors in cancer cells. Oncogene. 27(2): 225-233.

22. Chen K, Xiang Y, Yao X, Liu Y, Gong W, Yoshimura T, Wang JM. 2011. The active contribution of Toll-like receptors to allergic airway inflammation. Int Immunopharmacol. 11(10):

1391-1398.

23. Coban C, Igari $Y$, Yagi M, Reimer T, Koyama S, Aoshi T, Ohata K, Tsukui T, Takeshita F, Sakurai K, Ikegami T, Nakagawa A, Horii T, Nuñez G, Ishii KJ, Akira S. 2010. Immunogenicity of whole-parasite vaccines against Plasmodium falciparum involves malarial hemozoin and host TLR9. Cell Host Microbe. $7(1)$ :

50-61.

24. DeCarlo CA, Rosa B, Jackson R, Niccoli S, Escott NG, Zehbe I. 2011. Toll-like receptor transcriptome in the HPV-positive cervical cancer microenvironment. Clin Dev Immunol. 2012:

785825 .

25. Ewald SE, Engel A, Lee J, Wang M, Bogyo M, Barton GM. 2011. Nucleic acid recognition by Toll-like receptors is coupled to stepwise processing by cathepsins and asparagine endopeptidase. J Exp Med. 208(4): 643-651. 
26. Fichorova RN, Cronin AO, Lien E, Anderson DJ, Ingalls RR. 2002. Response to Neisseria gonorrhoeae by cervicovaginal epithelial cells occurs in the absence of toll-like receptor 4mediated signaling. J Immunol. 168(5): 24242432.

27. Fitzgerald KA, Rowe DC, Barnes BJ, Caffrey DR, Visintin A, Latz E, Monks B, Pitha PM, Golenbock DT. 2003. LPS-TLR4 signaling to IRF-3/7 and NF- $\kappa \mathrm{B}$ involves the toll adapters TRAM and TRIF. J Exp Med. 198(7): 10431055.

28. Fukui R, Saitoh S, Matsumoto F, Kozuka-Hata H, Oyama M, Tabeta K, Beutler B, Miyake K. 2009. Unc93B1 biases Toll-like receptor responses to nucleic acid in dendritic cells toward DNA-but against RNA-sensing. J Exp Med. 206(6): 1339-1350.

29. Garcia-Cattaneo A, Gobert FX, Müller $M$, Toscano F, Flores M, Lescure A, Del Nery E, Benaroch P. 2012. Cleavage of Toll-like receptor 3 by cathepsins $\mathrm{B}$ and $\mathrm{H}$ is essential for signaling. Proc Natl Acad Sci U S A. 109(23): 9053-9058.

30. Girling JE, Hedger MP. 2007. Toll-like receptors in the gonads and reproductive tract: emerging roles in reproductive physiology and pathology. Immunol Cell Biol. 85(6): 481-489.

31. Ghasemi N, Amjadi F, Salehi E, Shakeri M, Aflatoonian A, Aflatoonian R. 2014. Expression of Toll-like receptors 7-10 in human fallopian tubes. Iran J Reprod Med. 12(6): 389-394.

32. Goethals S, Ydens E, Timmerman V, Janssens S. 2010. Toll-like receptor expression in the peripheral nerve. Glia. 58(14): 1701-1709.

33. Hanke ML, Kielian T. 2011. Toll-like receptors in health and disease in the brain: mechanisms and therapeutic potential. Clin Sci (Lond). 121(9):

367-387.

34. Herath S, Williams EJ, Lilly ST, Gilbert RO, Dobson H, Bryant CE, Sheldon IM. 2007. Ovarian follicular cells have innate immune capabilities that modulate their endocrine function. Reproduction. 134(5): 683-693.

35. Hoffmann JA. 2003. The immune response of Drosophila. $\quad$ Nature. 426: 33-38.

36. Horng T, Barton GM, Flavell RA, Medzhitov R. 2002. The adaptor molecule TIRAP provides signalling specificity for Toll-like receptors.
Nature.

420(6913):

329-333.

37. Ito T, Amakawa R, Fukuhara S. 2002. Roles of toll-like receptors in natural interferon-producing cells as sensors in immune surveillance. Hum Immunol. 63(12): 1120-1125.

38. Jack CS, Arbour N, Manusow J, Montgrain V, Blain M, McCrea E, Shapiro A, Antel JP. 2005. TLR signaling tailors innate immune responses in human microglia and astrocytes. J Immunol. 175(7): 4320-4330.

39. Janeway CA, Medzhitov R. 2002. Innate immune recognition. Annu Rev Immunol. 20: 197-216.

40. Kalb ML, Glaser A, Stary G, Koszik F, Stingl G. 2012. TRAIL(+) human plasmacytoid dendritic cells kill tumor cells in vitro: mechanisms of imiquimod- and IFN- $\alpha$-mediated antitumor reactivity. J Immunol. 188(4): 1583-1591.

41. Kawai T, Akira S. 2010. The role of patternrecognition receptors in innate immunity: update on Toll-like receptors. Nat Immunol. 11(5): 373384.

42. Koblansky AA, Jankovic D, Oh H, Hieny S, Sungnak W, Mathur R, Hayden MS, Akira S, Sher A, Ghosh S. 2013. Recognition of profilin by Toll-like receptor 12 is critical for host resistance to Toxoplasma gondii. Immunity. 38(1):

119-130.

43. Kumar H, Kawai T, Akira S. 2011. Pathogen recognition by the innate immune system. Int. Rev. Immunol. 30(1): 16-34.

44. Kutikhin AG, Yuzhalin AE, 2015. Editorial: Pattern recognition receptors and cancer. Front Immunol.

6 :

481.

45. Lafferty EI, Qureshi ST, Schnare M. 2010. The role of toll-like receptors in acute and chronic lung inflammation. J Inflamm (Lond). 7(1): 57.

46. Lee BL, Moon JE, Shu JH, Yuan L, Newman ZR, Schekman R, Barton GM. (2013). UNC93B1 mediates differential trafficking of endosomal TLRs. Elife. 19: 2:e00291.

47. Lee SM, Kok KH, Jaume M, Cheung TK, Yip TF, Lai JC, Guan Y, Webster RG, Jin DY, Peiris JS. 2014. Toll-like receptor 10 is involved in induction of innate immune responses to influenza virus infection. Proc Natl Acad Sci U S
A.
111(10):
3793-3798. 
48. Lehnardt S, Lachance C, Patrizi S, Lefebvre S, Follett PL, Jensen FE, Rosenberg PA, Volpe JJ, Vartanian T. 2002. The toll-like receptor TLR4 is necessary for lipopolysaccharide-induced oligodendrocyte injury in the CNS. J Neurosci. 22(7):

2478-2486.

49. Lehnardt S, Henneke $\mathrm{P}$, Lien E, Kasper DL, Volpe JJ, Bechmann I, Nitsch R, Weber JR, Golenbock DT, Vartanian T. 2006. A mechanism for neurodegeneration induced by group B streptococci through activation of the TLR2/MyD88 pathway in microglia. J Immunol. 177(1):

583-592.

50. Lemaitre B, Nicolas E, Michaut L, Reichhart JM, Hoffmann JA. 1996. The dorsoventral regulatory gene cassette spätzle/Toll/cactus controls the potent antifungal response in Drosophila adults. $\begin{array}{lll}\text { Cell. } & \text { 86(6): }\end{array}$

51. Lin X, Fang D, Zhou H, Su SB. (2013). The expression of Toll-like receptors in murine Müller cells, the glial cells in retina. Neurol Sci. 34(8):

1339-1346.

52. Mathur R, Oh H, Zhang D, Park SG, Seo J, Koblansky A, Hayden MS, Ghosh S. 2012. A mouse model of Salmonella typhi infection. Cell. 151(3):

590-602.

53. Medzhitov R, Janeway CA Jr. 2002. Decoding the patterns of self and nonself by the innate immune system. Science. 296(5566): 298-300.

54. Ming Shi, Yuanfei Yao, Fang Han, Yiqun Li, Yu Li. 2014. MAP1S Controls Breast Cancer Cell TLR5 Signaling Pathway and Promotes TLR5 Signaling-based Tumor Suppression. PLoS One. 9(1):

e86839.

55. Narayanan KB, Park HH. 2015. Toll/interleukin1 receptor (TIR) domain-mediated cellular signaling pathways. Apoptosis. 20(2): 196-209.

56. Oldenburg M, Krüger A, Ferstl R, Kaufmann A, Nees G, Sigmund A, Bathke B, Lauterbach H, Suter M, Dreher S, Koedel U, Akira S, Kawai T, Buer J, Wagner $\mathrm{H}$, Bauer $\mathrm{S}$, Hochrein $\mathrm{H}$, Kirschning CJ. 2012. TLR13 recognizes bacterial 23S rRNA devoid of erythromycin resistance-forming modification. Science. 337(6098):

1111-1115.

57. Oshiumi H, Sasai M, Shida K, Fujita $T$, Matsumoto M, Seya T. 2003. TIR-containing adapter molecule (TICAM)-2, a bridging adapter recruiting to Toll-like receptor 4 TICAM-1 that induces interferon- $\beta$. J Biol Chem. 278(50):
49751-49762.

58. Otte JM, Cario E, Podolsky DK. 2004. Mechanisms of cross hyporesponsiveness to Toll-like receptor bacterial ligands in intestinal epithelial cells. Gastroenterology. 126(4): 10541070 .

59. Palladino MA, Savarese MA, Chapman JL, ve ark. 2008. Localization of toll-like receptors on epididymal epithelial cells and spermatozoa. Am J Reprod Immunol. 60(6): 541-555.

60. Pisetsky DS, Gauley J, Ullal AJ. 2011. HMGB1 and microparticles as mediators of the immune response to cell death. Antioxid Redox Signal. 15(8):

2209-2219.

61. Riccioli A, Starace D, Galli R, Fuso A, Scarpa S, Palombi F, De Cesaris P, Ziparo E, Filippini A. 2006. Sertoli cells initiate testicular innate immune responses through TLR activation. J Immunol. $\quad$ 177(10): 7122-7130.

62. Ridnour LA, Cheng RY, Switzer CH, Heinecke JL, Ambs S, Glynn S, Young HA, Trinchieri G, Wink DA. 2013. Molecular pathways: toll-like receptors in the tumor microenvironment--poor prognosis or new therapeutic opportunity. Clin Cancer Res. 19(6): 1340-1346.

63. Rock FL, Hardiman G, Timans JC, Kastelein RA, Bazan JF. 1998. A family of human receptors structurally related to Drosophila Toll. Proc Natl Acad Sci U S A. 95(2): 588-593.

64. Sasai M, Linehan MM, Iwasaki A. 2010. Bifurcation of Toll-like receptor 9 signaling by adaptor protein 3. Science. 329(5998): 15301534.

65. Sha Q, Truong-Tran AQ, Plitt JR, Beck LA, Schleimer RP. 2004. Activation of airway epithelial cells by toll-like receptor agonists. Am J Respir Cell Mol Biol. 31(3): 358-364.

66. Shang T, Zhang X, Wang T, Sun B, Deng T, Han D. (2011). Toll-like receptor-initiated testicular innate immune responses in mouse Leydig cells. Endocrinology. 152(7): 2827-2836.

67. Shatz M, Menendez D, Resnick MA. (2012). The human TLR innate immune gene family is differentially influenced by DNA stress and p53 status in cancer cells. Cancer Res. 72(16): 39483957.

68. Shi Z, Cai Z, Sanchez A, Zhang T, Wen S, Wang J, Yang J, Fu S, Zhang D. 2011. A novel Toll- 
like receptor that recognizes vesicular stomatitis virus. J Biol Chem. 286(6): 4517-4524.

69. Smith MF Jr, Mitchell A, Li G, Ding S, Fitzmaurice AM, Ryan K, Crowe S, Goldberg JB. 2003. Toll-like receptor (TLR) 2 and TLR5, but not TLR4, are required for Helicobacter pylori-induced $\mathrm{NF}-\kappa \mathrm{B}$ activation and chemokine expression by epithelial cells. J Biol Chem. 278: 32552-32560.

70. Szretter KJ, Samuel MA, Gilfillan S, Fuchs A, Colonna M, Diamond MS. 2009. The immune adaptor molecule SARM modulates tumor necrosis factor alpha production and microglia activation in the brainstem and restricts West Nile Virus pathogenesis. J Virol. 83(18): 9329 9338.

71. Takahashi K, Shibata T, Akashi-Takamura S, Kiyokawa T, Wakabayashi Y, Tanimura N, Kobayashi T, Matsumoto F, Fukui R, Kouro T, Nagai Y, Takatsu K, Saitoh S, Miyake K. 2007. A protein associated with Toll-like receptor (TLR) 4 (PRAT4A) is required for TLRdependent immune responses. J Exp Med. 204(12): 2963-2976.

72. Takeuchi O, Kawai T, Sanjo H, Copeland NG, Gilbert DJ, Jenkins NA, Takeda K, Akira S. 1999. TLR6: A novel member of an expanding toll-like receptor family. Gene. 231(1-2): 59-65.

73. Tang SC, Arumugam TV, $\mathrm{Xu} \mathrm{X}$, Cheng A, Mughal MR, Jo DG, Lathia JD, Siler DA, Chigurupati S, Ouyang $\mathrm{X}$, Magnus $\mathrm{T}$, Camandola S, Mattson MP. 2007. Pivotal role for neuronal Toll-like receptors in ischemic brain injury and functional deficits. Proc Natl Acad Sci U S A. 104(34): 13798-13803.

74. Winnall WR, Muir JA, Hedger MP. 2011. Differential responses of epithelial Sertoli cells of the rat testis to Toll-like receptor 2 and 4 ligands: implications for studies of testicular inflammation using bacterial lipopolysaccharides. Innate Immun. 17(2): 123136.
75. Yamamoto M, Sato S, Hemmi H, Sanjo H, Uematsu S, Kaisho T, Hoshino K, Takeuchi O, Kobayashi M, Fujita T, Takeda K, Akira S. 2002. Essential role for TIRAP in activation of the signalling cascade shared by TLR2 and TLR4. Nature. 420(6913): 324-329.

76. Yamamoto M, Sato S, Hemmi H, Uematsu S, Hoshino K, Kaisho T, Takeuchi O, Takeda K, Akira S. 2003. TRAM is specifically involved in the Toll-like receptor 4-mediated MyD88independent signaling pathway. Nat Immunol. 4: 1144-1150.

77. Yang Y, Liu B, Dai J, Srivastava PK, Zammit DJ, Lefrançois L, Li Z. 2007. Heat shock protein gp96 is a master chaperone for toll-like receptors and is important in the innate function of macrophages. Immunity. 26(2): 215-226.

78. Yarovinsky F, Zhang D, Andersen JF, Bannenberg GL, Serhan CN, Hayden MS, Hieny S, Sutterwala FS, Flavell RA, Ghosh S, Sher A. 2005. TLR11 activation of dendritic cells by a protozoan profilin-like protein. Science. 308(5728): 1626-1629.

79.Zarember KA, Godowski PJ. 2002. Tissue expression of human Toll-like receptors and differential regulation of Toll-like receptor mRNAs in leukocytes in response to microbes, their products, and cytokines. J Immunol. 168(2): 554-561. 